\title{
Examination of the Effect of the Combined Use of Nd: YAG Laser Irradiation and Mechanical Force Loading on Bone Metabolism Using Cultured Human Osteoblasts
}

\author{
Yuji Tsuka', Ryo Kunimatsu' ${ }^{1 *}$, Hidemi Gunji ${ }^{1}$, Takaharu Abe ${ }^{1}$, Cynthia Concepción Medina ${ }^{1}$, Kengo Nakajima ${ }^{1}$, \\ Aya Kimura', Tomoka Hiraki ${ }^{2}$, Ayaka Nakatani ${ }^{2}$, Kotaro Tanimoto ${ }^{1}$ \\ ${ }^{1}$ Department of Orthodontics, Division of Oral Health and Development, Hiroshima University Hospital, Hiroshima, Japan \\ ${ }^{2}$ Department of Orthodontics, Applied Life Sciences, Hiroshima University Institute of Biomedical \& Health Sciences, \\ Hiroshima, Japan
}

\author{
*Correspondence to \\ Ryo Kunimatsu, Department \\ of Orthodontics, Division of \\ Oral Health and Development, \\ Hiroshima University Hospital, \\ 1-2-3 Kasumi, Minami-ku, \\ Hiroshima 734-8553, Japan. \\ Tel: +81-82-257-5686; \\ Fax: +81-82-257-5687; \\ Email: \\ ryoukunimatu@hiroshima-u.ac.jp
}

Published online March 15 2020

\begin{abstract}
Introduction: In recent years, laser irradiation in the near-infrared ray (NIR) area has been reported to promote bone healing. There are also reports that laser irradiation accelerates orthodontic tooth movement. In this study, we investigated the effect of NIR laser irradiation and mechanical stimulation on osteoblasts.

Methods: We seeded osteoblast-like cells and laser irradiation was performed 24 hours after cell seeding. In addition, a control group not receiving anything, a group receiving only Nd: YAG (neodymium-doped yttrium aluminum garnet) laser irradiation, a group receiving only centrifugal loading, and a group receiving both Nd: YAG laser irradiation and centrifugal force loading were set, and after 24 hours and after 48 hours, cells were collected and quantitative real-time polymerase chain reaction (PCR) was performed.

Results: 24 hours after laser irradiation, the gene expression of alkaline phosphatase (ALP), the receptor activator of NF- $\mathrm{KB}$ ligand (RANKL) and osteoprotegerin (OPG) was significantly higher in the $2.0 \mathrm{~W}$ group than in the control group. In addition, the RANKL/OPG ratio was higher in the $2.0 \mathrm{~W}$ group than in the control group. Also, in the group using laser irradiation and centrifugal loading in combination, 24 hours after laser irradiation, ALP and OPG showed significantly higher values than those in the centrifugal load only group. Furthermore, the RANKL/OPG ratio also showed high values.

Conclusion: These results suggest that osteoblast-like cells activate genes related to bone metabolism by combining mechanical stimulation and laser irradiation. This helps to elucidate the influence of laser irradiation during tooth movement.

Keywords: Nd: YAG laser; Bone metabolism; Osteoblast; Mechanical force.
\end{abstract}

\section{Introduction}

Laser therapy is developing in the medical field. In clinical practice in the field of dentistry, lasers have wide applications. Currently, lasers used in the dental field are surface absorption type ( $\mathrm{CO}_{2}$ laser and erbiumdoped yttrium aluminium garnet [YAG] laser) and tissue penetrating type lasers (He: Ne laser, neodymiumdoped yttrium aluminum garnet [Nd: YAG] laser, and diode laser). In cases where tissue incision and hemostasis are required, it is advantageous to use surface absorbing lasers at high power. In contrast, using tissue penetrating lasers at low power allows treatment using cell activation. In recent years, laser therapy in the nearinfrared region (NIR) has attracted attention. These are used for periodontal therapy, ${ }^{1,2}$ sensory hypersensitivity treatment, ${ }^{3,4}$ and treatment of temporomandibular disorders. ${ }^{5}$ On another study using a rat fracture model, there were reports that $\mathrm{Nd}$ : YAG laser and diode laser irradiation promoted bone healing ${ }^{6,7}$ and that diode laser irradiation promoted bone grafting in rats and in vitro experiments. ${ }^{8,9}$ Also, another study reports that Nd: YAG laser irradiation promoted osteoblast differentiation, ${ }^{10}$ red laser irradiation caused fibroblast proliferation, ${ }^{11}$ and diode laser irradiation caused osteoblast proliferation. ${ }^{12}$ In the field of orthodontic dentistry, pain relief ${ }^{13,14}$ during tooth movement by laser irradiation and the acceleration of tooth movement have been reported. ${ }^{15-17}$ However, it is currently the case that there are many things the

Please cite this article as follows: Tsuka Y, Kunimatsu R, Gunji H, Abe T, Medina CC, Nakajima K, et al. Examination of the effect of the combined use of $\mathrm{Nd}$ : YAG laser irradiation and mechanical force loading on bone metabolism using cultured human osteoblasts. I Lasers Med Sci. 2020;11(2):138-143. doi:10.34172/jlms.2020.24. 
mechanisms of which are not known yet. In previous experiments, the irradiation effect of the Nd: YAG laser during orthodontic tooth movement was investigated using rats and it was proved that there was a change in bone metabolism and tooth movement. ${ }^{18}$ In addition, in a previous study from the authors, a wound healing test was performed by irradiating osteoblast-like cells with a diode laser and confirmed that the cells proliferated. ${ }^{12}$

There are many researches using the Nd: YAG laser in in vitro experiments, but there is no cell experiment model considering tooth movement. There are several reports that are used as cell experimental models of tooth movement by applying a mechanical stimulus to cells. ${ }^{19}$ Therefore, it was decided to investigate the effect of the irradiation of the Nd: YAG laser on the condition that the osteoblast-like cells were loaded with mechanical stimulation by centrifugal force.

\section{Methods}

\section{Cell Culture}

Cells of the human-derived osteoblast-like cells line Saos-2 (Riken, Tukuba, Japan ) were cultured in 100mm (Corning, NY, USA) tissue culture dishes with the Dulbecco's Modified Eagle Medium (DMEM; Sigma, St. Louis, MO) supplemented with $10 \%$ fetal bovine serum (FBS; Bioserum, Melbourne, Victoria, Australia) and $50 \mathrm{mg} / \mathrm{mL}$ kanamycin (Meiji Pharmaceutical, Tokyo, Japan). Incubation was done at $37^{\circ} \mathrm{C}$ under a humidified atmosphere of $95 \%$ air and $5 \% \mathrm{CO} 2$. The exchange of the culture medium was done every 3 days. The passage was carried out when the confluence reached $80 \%$.

\section{Preliminary Experiment for Determining Conditions} $5.0 \times 10^{4}$ cells were seeded in a 24 -well plate and the $\mathrm{Nd}$ : YAG laser was irradiated under the conditions of $0.6 \mathrm{~W}$, $2.0 \mathrm{~W}, 4.0 \mathrm{~W}$, and $6.0 \mathrm{~W}$ after 24 hours. The cells were collected using PBS (Mitsubishi Chemical Mediation, Tokyo, Japan) containing $0.2 \%$ trypsin (Nakarai Tesque, Kyoto, Japan) and 0.1\% EDTA (Wako, Tokyo, Japan) 24 hours after Nd: YAG laser irradiation, with the number of viable cells counted using a $0.4 \mathrm{w} / \mathrm{v} \%$ trypan blue solution (Wako). As a result, it was found that the cells died when the output was $4.0 \mathrm{~W}$ or more. Therefore, it was decided to experiment with control, $0.6 \mathrm{~W}$, and $2.0 \mathrm{~W}$ conditions (Figure 1).

\section{Laser Irradiation}

For this study, the Nd: YAG laser (Inpulse, Incisive, Richmond, Ca, USA) with a wavelength of $1064 \mathrm{~nm}$ was used. The guide light was a diode laser with a wavelength of 630 to $680 \mathrm{~nm}$. A $0.32-\mathrm{mm}$ optical fiber was used as the tip of the Nd: YAG laser. The handpiece was set using a stand so that the distance from the tip to the bottom of the culture dish was $2.4 \mathrm{~cm}$. Laser irradiation was performed for 15 seconds under each condition. Energy density was $5.17 \mathrm{~J} / \mathrm{cm}^{2}(0.6 \mathrm{~W}), 17.23 \mathrm{~J} / \mathrm{cm}^{2}(2.0 \mathrm{~W}), 34.47 \mathrm{~J} / \mathrm{cm}^{2}$

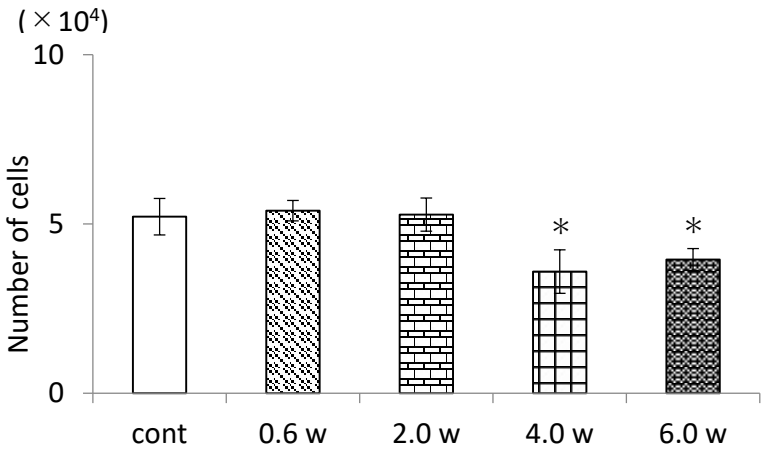

Figure 1. Number of Cells After Nd:YAG Laser Irradiation for 24 Hours. cont: Control group not irradiated with the Nd: YAG laser.

$0.6 \mathrm{~W}, 2.0 \mathrm{~W}, 4.0 \mathrm{~W}, 6.0 \mathrm{~W}$ : Experimental groups irradiated with the $\mathrm{Nd}$ : YAG laser at each output. $* P<0.05$ vs. control, $\mathrm{n}=3$.

Human-derived osteoblast-like cells were irradiated with the Nd: YAG laser and the number of viable cells was determined 24 hours later.

When the cells were irradiated with the Nd: YAG laser at an output of 4.0 $W$ or higher, a decrease in the number of viable cells was observed.

$(4.0 \mathrm{~W})$, and $51.7 \mathrm{~J} / \mathrm{cm}^{2}(6.0 \mathrm{~W})$ in total. Also, the nonirradiated cultured cells were used as the control. The specifications of laser irradiation are shown in Table 1.

\section{Quantitative Real-Time PCR Analysis}

$2.0 \times 10^{5}$ cells were seeded in a 24 -well plate and the Nd: YAG laser irradiated each condition after 24 hours. 24 hours after laser irradiation, the cells were collected using PBS containing $0.2 \%$ trypsin and $0.1 \%$ EDTA, homogenized using a syringe and a $20 \mathrm{G}$ needle (both Terumo, Tokyo, Japan), and the RNeasy Mini Kit (RNeasy Mini Spin Colum, QIAGEN, Venlo, Netherlands) RNA was extracted by the column method used (Figure 2).

The total RNA was quantified by reading the absorbance at a wavelength of $260 \mathrm{~nm}$ by a spectrophotometer (BioSpecnano, Shimadzu, Kyoto, Japan). The cDNA was synthesized from $1 \mathrm{mg}$ total RNA using a qPCR reverse transcription kit (ReverTra Ace- $\alpha$, Toyobo, Osaka, Japan) and a random primer (Toyobo). The cDNA was obtained from total RNA using a Simpli Amp Thermal Cycler (Applied Biosystems, Foster City, CA, USA). Gene expression was monitored using the SYBR Green Real-time PCR Master Mix (Toyobo, Osaka, Japan) and a Light Cycler 480 II system (Roche Diagnostics, Basel, Switzerland) with the prepared cDNA as the

Table 1. The Specifications of the Nd: YAG Laser Used in This Study

\begin{tabular}{lc}
\hline Wavelength $(\mathbf{n m})$ & 1064 \\
\hline Operating mode & Pulsed \\
\hline Frequency $(\mathbf{H z})$ & $20-30$ \\
\hline Pulse duration $(\boldsymbol{\mu s})$ & 100 \\
\hline Duty cycle & 0.001 \\
\hline Power & $30-200 \mathrm{~mJ} / 100 \mu \mathrm{s}$ \\
\hline Average power $(\mathbf{W})$ & $0.6-6.0$ \\
\hline
\end{tabular}




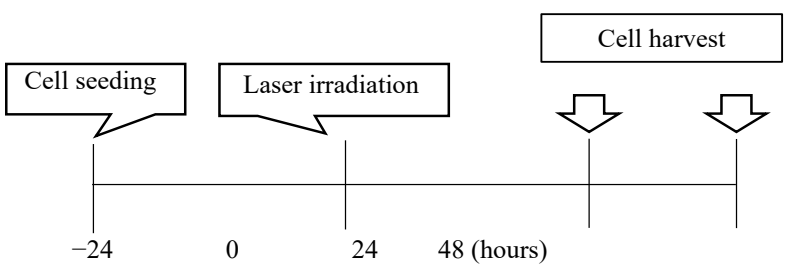

Figure 2. The Time Course of This Experiment.

template. Table 2 shows the PCR primer sequences for alkaline phosphatase (ALP), Receptor activator of NF$\kappa \mathrm{B}$ ligand (RANKL) and osteoprotegerin (OPG) and glyceraldehyde-3-phosphate dehydrogenase (GAPDH). The reaction conditions were as follows: 45 cycles of denaturation at $95^{\circ} \mathrm{C}$ for 15 seconds, annealing at $55^{\circ} \mathrm{C}$ for 30 seconds, and extension at $72^{\circ} \mathrm{C}$ for 10 seconds. Gene expression values were normalized to the control values. The fold-increase in gene expression in human-derived osteoblast-like cells cultured alone was also monitored, and the mRNA level was normalized to that of GAPDH.

\section{Mechanical Stress}

Centrifugal force was applied for 20 minutes at $489 \mathrm{rpm}$ using RPM LCO 6-SP (Tommy Seiko, Tokyo, Japan), following the method described by Redlich et al. ${ }^{19}$ After centrifugal force loading, the laser was irradiated, cell recovery was performed after 24 and 48 hours, and the RTPCR experiment was performed using the same method. For the cells subjected to both centrifugal loading and laser irradiation, a laser irradiation setting of $2.0 \mathrm{~W}$, which was the most effective, was selected.

\section{Statistical Analysis}

The mean of the three experiments was calculated and was considered to represent the values of each experimental parameter. The data from the three independent experiments are presented as the mean and standard deviation. One-way analysis of variance was used for group comparisons. The differences between the control group and each experimental group were analyzed by the Dunnett test. $P$ values of $\leq 0.05$ were considered statistically significant.

Table 2. PCR Primer Sequences

\begin{tabular}{ll}
\hline Gene & Sequence \\
\hline \multirow{2}{*}{ GAPDH } & $\begin{array}{l}\text { Forward 5'-TGGTATCGTGGAAGGACTCA-3' } \\
\text { Reverse 5'-GCCATCACGCCACAGTT-3' }\end{array}$ \\
\multirow{2}{*}{ ALP } & Forward 5'-TACAAGGTGGGCGGTGA-3' \\
& Reverse 5'-ACAGCAGACTGCGCCTGGTAGTT-3' \\
\multirow{2}{*}{ RANKL } & Forward 5'-ATATCGTTGGATCACAGCAC-3' \\
& Reverse 5'-CAAGAGGACAGACTCACTTTATG-3' \\
OPG & Forward 5'-CTGCTGAAGTTATGGAAACAT-3' \\
& Reverse 5'-AGGTTAGCATGTCCAATGTG-3' \\
\hline
\end{tabular}

\section{Results}

Compared with the control group, the expression of the RANKL, OPG, and ALP genes 24 hours after irradiation was not significantly different in the $0.6 \mathrm{~W}$ laser irradiation group but significantly higher in the 2.0 $\mathrm{W}$ laser irradiation group. Furthermore, the RANKL/ OPG ratio did not change significantly in the $0.6 \mathrm{~W}$ laser irradiation group compared to the control group but was higher in the $2.0 \mathrm{~W}$ laser irradiation group compared with the control group (Figure 3 ).

Compared with the control group, there was no significant difference in RANKL, OPG, and ALP gene expression 48 hours after the start of the experiment in the $0.6 \mathrm{~W}$ and $2.0 \mathrm{~W}$ laser irradiation groups. In addition, there was no difference in the RANKL/OPG ratio between the $0.6 \mathrm{~W}$ and $2.0 \mathrm{~W}$ laser irradiation groups compared to the control group (Figure 4).

The gene expressions of OPG, RANKL and ALP were significantly higher in the Nd: YAG laser irradiation group and the centrifugal force load group than in the control group 24 hours after the experiment. In addition, the gene expression of RANKL and ALP was significantly higher in the laser centrifugal load group than the centrifugal load group, and OPG gene expression was significantly lower.

The RANKL/OPG ratio was higher in all experimental groups compared to the control group. In particular, the laser irradiation/centrifugal loading group exhibited the highest ratio (Figure 5).

The expression of the ALP gene 48 hours after the experiment was significantly higher in the $\mathrm{Nd}$ : YAG laser irradiation and the centrifugal load group than in
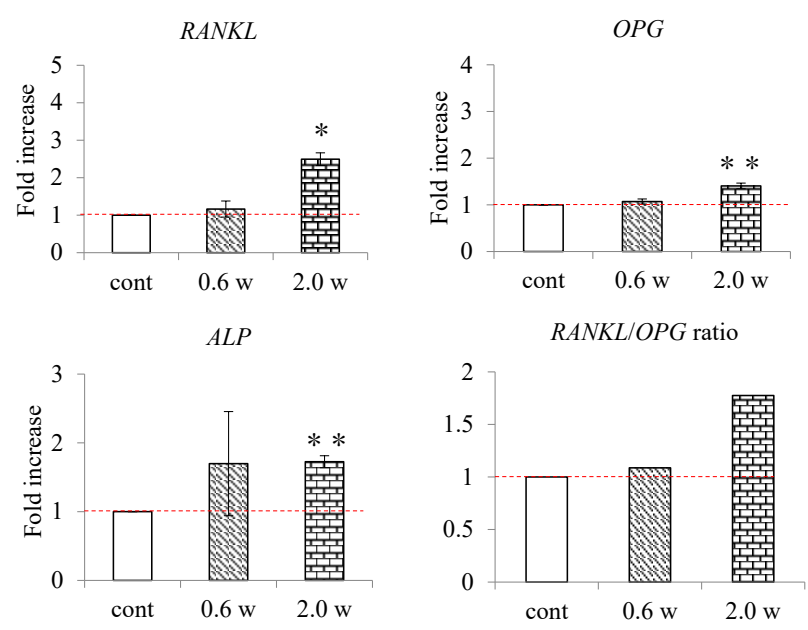

Figure 3. RANKL, OPG, and $A L P$ Gene Expression Levels 24 Hours After $\mathrm{Nd}$ :YAG Laser Irradiation.

cont: Control group not irradiated with the Nd: YAG laser.

$0.6 \mathrm{~W}, 2.0 \mathrm{~W}$ : Experiment groups irradiated with the $\mathrm{Nd}$ : YAG laser at each output. ${ }^{* *} P<0.01, * P<0.05$ vs. control; $\mathrm{n}=3$.

The graphs show the fold-increase in the expression of the RANKL, OPG, and $A L P$ genes 24 hours after Nd: YAG laser irradiation.

The expression of the RANKL, OPG, and ALP genes and the RANKL/OPG ratio 24 hours after irradiation were higher in the $2.0 \mathrm{~W}$ laser irradiation group than in the control group. 

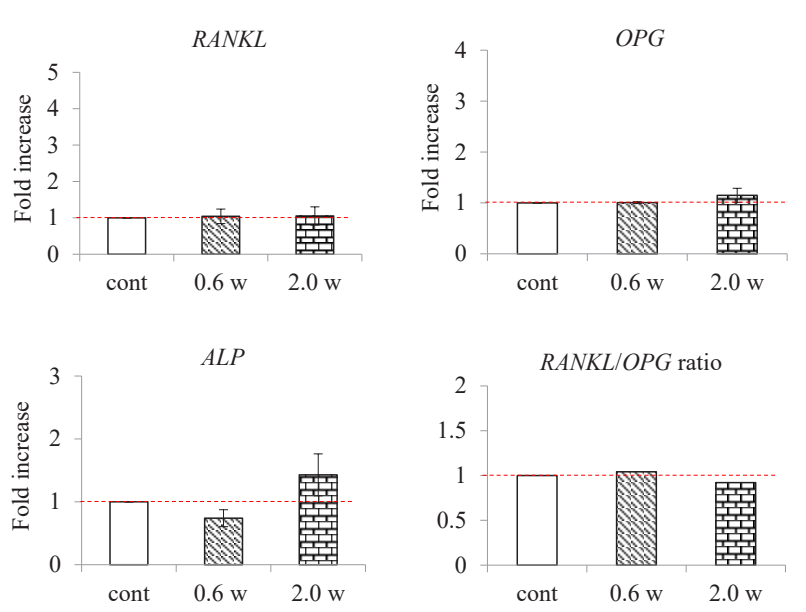

Figure 4. RANKL, $O P G$, and $A L P$ Gene Expression Levels 48 Hours After $\mathrm{Nd}$ :YAG Laser Irradiation.

cont: Control group not irradiated with the $\mathrm{Nd}$ : YAG laser.

$0.6 \mathrm{~W}, 2.0 \mathrm{~W}$ : Experiment groups irradiated with an Nd: YAG laser at each output. ${ }^{*} P<0.01, * P<0.05$ vs. control; $\mathrm{n}=3$.

The graphs show the fold-increase in the expression of the RANKL, OPG, and $A L P$ genes 48 hours after irradiation with an Nd: YAG laser. 48 hours after the start of the experiment, there was no significant difference in gene expression between the control and experimental groups.
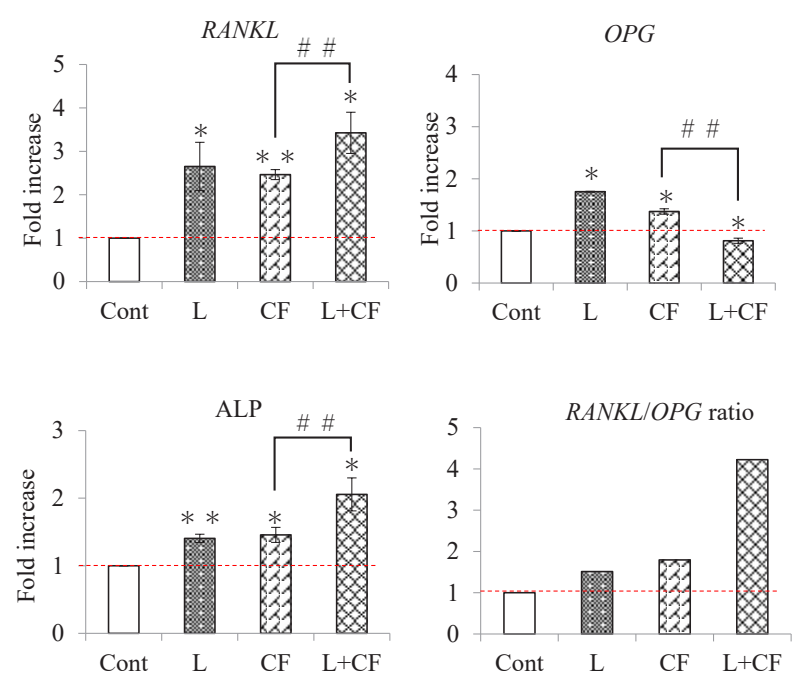

Figure 5. RANKL, OPG, and ALP Gene Expression Levels 24 Hours After $\mathrm{Nd}$ :YAG Laser Irradiation and Centrifugal Force.

Cont: Control group not treated with $\mathrm{Nd}$ : YAG laser irradiation and centrifugal force loading.

L: Experiment group irradiated with an Nd: YAG laser at an output of 2.0 W. CF: Experimental group subjected to centrifugal force as a mechanical stress. L+CF: Experimental group in which centrifugal force was applied as a mechanical stress and $\mathrm{Nd}$ : YAG laser irradiation was performed at an output of $2.0 \mathrm{~W}$.

${ }^{* *} P<0.01, * P<0.05$ vs. control; $\mathrm{n}=3 . \# \# P<0.01$ vs. $\mathrm{CF} ; \mathrm{n}=3$.

The graphs show the fold-increase in the expression of the RANKL, OPG, and $A L P$ genes 24 hours after Nd: YAG laser irradiation and centrifugal force loading.

The RANKL/OPG ratio was higher in the laser irradiation/centrifugal force loading group compared to the other groups.

the control group. There were no significant differences compared to the other groups (Figure 6).
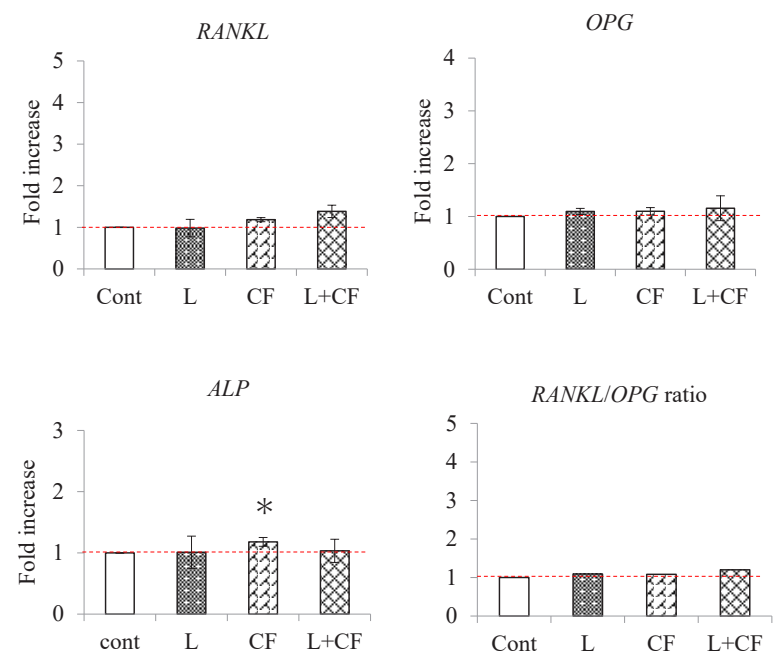

Figure 6. RANKL, OPG, and ALP Gene Expression Levels 24 Hours After $\mathrm{Nd}$ :YAG Laser Irradiation and Centrifugal Force.

Cont: Control group not treated with $\mathrm{Nd}$ : YAG laser irradiation and centrifugal force loading.

L: Experiment group treated with Nd: YAG laser irradiation at an output of $2.0 \mathrm{~W}$. CF: Experimental group treated with centrifugal force as a mechanical stress. L+CF: Experimental group in which centrifugal force was applied as a mechanical stress and Nd: YAG laser irradiation was performed at an output of $2.0 \mathrm{~W}$.

$* P<0.05$ vs. control; $\mathrm{n}=3$.

The graphs show the fold-increase in the expression of the RANKL, OPG, and $A L P$ genes 48 hours after treatment with $\mathrm{Nd}$ : YAG laser irradiation and centrifugal force loading.

The RANKL/OPG ratio, 48 hours after the experiment was initiated, tended to be higher in the experimental groups than in the control group, but there was no significant difference in RANKL and OPG expression.

\section{Discussion}

In the setting of this study, preliminary experiments were performed by irradiating the cells with an Nd: YAG laser. Compared to the control group, there was no significant difference in the $0.6 \mathrm{~W}$ and $2.0 \mathrm{~W}$ groups, but the number of human-derived osteoblast-like cells was significantly reduced in both the $4.0 \mathrm{~W}$ and $6.0 \mathrm{~W}$ groups. According to the Arndt-Schulz's law, weak stimuli promote the reaction both biologically and physiologically, and the strong stimulus suppresses this reaction and is said to be harmful. ${ }^{20,21}$ The results of the preliminary experiment indicated that a harmful reaction to irradiation occurred in the cells in the 4.0 and $6.0 \mathrm{~W}$ groups. Our previous experiments demonstrated that human-derived osteoblast-like cells irradiated with an Nd: YAG laser were induced to proliferate..$^{22}$ In the present study, no proliferation of live cells was observed, potentially because the cells were not damaged by scratches and therefore the response may be different. When combined with the defense responses of the living body, the laser effect may be more likely. In another study, cell proliferation was confirmed by NIR laser irradiation of osteoblast-like cells (MC3T3-E1). ${ }^{12}$ However, the cells did not proliferate in the present study. This could be related to the use of a different cell type and differences in experimental methods for confirming cell growth. Another potential 
factor is the laser; although the output was similar, the use of a different type of laser could have affected the results.

Several reports on the effects of $\mathrm{Nd}$ : YAG laser irradiation on cells have been published. It was reported that an increase in intracellular $\mathrm{Ca}^{2+}$ in osteoblast-like cells was observed in the Nd: YAG laser-irradiated group via the activation of the TRPC1 ion channel compared to the control, reported by Chellini et al. ${ }^{10}$ Ninomiya et al reported that bone formation was promoted by irradiating the damaged rat femur with the Nd: YAG laser compared to the control group. ${ }^{6}$ Thus, laser irradiation is thought to have a beneficial effect on bone formation. It has been reported that low-power laser irradiation in a rat tooth movement model resulted in increased OPG expression compared to the control group. ${ }^{23}$ Oliveira et al reported that ALP activity increased in cells irradiated with a laser at the wavelengths of $660 \mathrm{~nm}$ and $780 \mathrm{~nm} \cdot{ }^{24}$

In the present study, the expression of the OPG and ALP genes was significantly higher in the $2.0 \mathrm{~W}$ group 24 hours after Nd: YAG laser irradiation. In the previous reports, it was confirmed that laser irradiation had a positive effect on bone formation. It was also reported that RANKL expression in a rat tooth movement model increased compared to the control group following lowpower laser irradiation. ${ }^{25}$ The results of the present study were similar, with RANKL gene expression significantly higher in the $2.0 \mathrm{~W}$ group 24 hours after Nd: YAG laser irradiation. Our experiments also demonstrated that the RANKL/OPG ratio was higher than that of the control group 24 hours after laser irradiation. This appears to be related to having a negative effect on bone formation. However, the sequence of reactions between tooth movement and laser irradiation is complex and cannot be explained at a single point. Tanaka et $\mathrm{al}^{26}$ reported that enhanced bone resorption was associated with an increase in the RANKL/OPG ratio. In addition, Oliveira et $\mathrm{al}^{24}$ reported increased ALP activity in cells irradiated with a laser at the wavelengths of $660 \mathrm{~nm}$ and $780 \mathrm{~nm}$. Similar results were obtained in the present study, suggesting that both the bone metabolism and resorption systems may be activated. Usumez et $\mathrm{al}^{27}$ reported that $\mathrm{Nd}$ : YAG laser irradiation in a rat gingival wound model resulted in increased expression of the TGF- $\beta$, PDGF, and bFGF genes compared to the control group. Likewise, in the present study, the activation of the cells by laser irradiation may have affected gene expression.

Naito et al reported that centrifugal loading significantly increased ALP gene expression on rat bone marrowderived osteoblasts. ${ }^{28}$ Also, Okamoto et al ${ }^{29}$ reported that RANKL gene expression increased due to centrifugal loading on MC3T3-E1 cells, and Naruse et $\mathrm{al}^{30}$ reported the increased expression of the OPG gene by centrifugal loading on cultured periodontal ligament cells. Similarly, in this study, the gene expression of OPG, RANKL and ALP was significantly higher in the load group than in the control group. Furthermore, when Nd: YAG laser irradiation was used in combination, the gene expression of ALP and RANKL was higher in the laser load group after 24 hours than in the load group. In addition, the gene expression of OPG showed significantly lower values in the laser load group than in the load group after 24 hours, resulting in a high RANKL/OPG ratio.

These results suggest that combining mechanical stimulation with $\mathrm{Nd}$ : YAG laser irradiation may increase ALP gene expression and the RANKL/OPG ratio in human osteoblast-like cells. Furthermore, under the present research conditions, the effect of $\mathrm{Nd}$ : YAG laser irradiation on osteoblast-like cells did not last for 48 hours, suggesting that the effect of laser irradiation decreases with time.

It was found that Nd: YAG Laser irradiation acted on osteoblast-like cells and activated the genes related to the bone metabolism system. Through further research, it is expected that it will have a positive impact on bone metabolism during tooth movement in orthodontic treatment.

\section{Conclusion}

These results suggest that osteoblast-like cells activate the genes related to bone metabolism by combining mechanical stimulation and laser irradiation. This helps to elucidate the influence of laser irradiation during tooth movement. The mechanics of laser irradiation and tooth movement are very complex. In addition, these reactions occur simultaneously, increasing complexity. Further detailed research is needed.

\section{Ethical Considerations}

Not applicable.

\section{Conflict of interest}

The authors declare that they have no conflict of interest.

\section{Acknowledgments}

This study was supported by grants from JSPS KAKENHI (numbers 16K11790, 16K20644, 25862016 and 18K17256). The authors declare no potential conflicts of interest with respect to the authorship and/or publication of this article.

\section{References}

1. Alzoman HA, Diab HM. Effect of gallium aluminium arsenide diode laser therapy on Porphyromonas gingivalis in chronic periodontitis: a randomized controlled trial. Int $J$ Dent Hyg. 2016;14(4):261-266. doi: 10.1111/idh.12169.

2. Gündoğar H, Şenyurt SZ, Erciyas K, Yalım M, Üstün K. The effect of low-level laser therapy on non-surgical periodontal treatment: a randomized controlled, single-blind, splitmouth clinical trial. Lasers Med Sci. 2016;31(9):1767-1773. doi: 10.1007/s10103-016-2047-z.

3. García-Delaney C, Abad-Sánchez D, Arnabat-Domínguez J, Valmaseda-Castellón E, Gay-Escoda C. Evaluation of the effectiveness of the photobiomodulation in the treatment 
of dentin hypersensitivity after basic therapy. A randomized clinical trial. J Clin Exp Dent. 2017;9(5):e694-e702. doi: $10.4317 /$ jced. 53635 .

4. Femiano F, Femiano R, Lanza A, Lanza M, Perillo L. Effectiveness on oral pain of 808-nm diode laser used prior to composite restoration for symptomatic non-carious cervical lesions unresponsive to desensitizing agents. Lasers Med Sci. 2017;32(1):67-71. doi: 10.1007/s10103-016-2087-4.

5. Sayed N, Murugavel C, Gnanam A. Management of temporomandibular disorders with low level laser therapy. J Maxillofac Oral Surg. 2014;13(4):444-50. doi: 10.1007/ s12663-013-0544-1.

6. Ninomiya T, Miyamoto $\mathrm{Y}$, Ito $\mathrm{T}$, Yamashita A, Wakita M, Nishisaka T. High-intensity pulsed laser irradiation accelerates bone formation in metaphyseal trabecular bone in rat femur. J Bone Miner Metab. 2003;21(2):67-73. doi: $10.1007 /$ s007740300011.

7. Weber JB, Pinheiro AL, de Oliveira MG, Oliveira FA, Ramalho LM. Laser therapy improves healing of bone defects submitted to autologous bone graft. Photomed Laser Surg. 2006;24(1):38-44. doi: 10.1089/pho.2006.24.38.

8. Son J, Kim YB, Ge Z, Choi SH, Kim G. Bone healing effects of diode laser $(808 \mathrm{~nm})$ on a rat tibial fracture model. In Vivo. 2012;26(4):703-9.

9. Pinheiro AL, Soares LG, Marques AM, Cangussú MC, Pacheco MT, Silveira L Jr. Biochemical changes on the repair of surgical bone defects grafted with biphasic synthetic microgranular $\mathrm{HA}+\beta$-tricalcium phosphate induced by laser and LED phototherapies and assessed by Raman spectroscopy. Lasers Med Sci. 2017;32(3):663-72. doi: 10.1007/s10103-0172165-2.

10. Chellini F, Sassoli C, Nosi D, Deledda C, Tonelli P, ZecchiOrlandini S, et al. Low pulse energy Nd:YAG laser irradiation exerts a biostimulative effect on different cells of the oral microenvironment: "an in vitro study". Lasers Surg Med. 2010;42(6):527-39. doi: 10.1002/1sm.20861.

11. Naderi MS, Razzaghi M, Esmaeeli Djavid G, Hajebrahimi Z. A comparative study of $660 \mathrm{~nm}$ low-level laser and light emitted diode in proliferative effects of fibroblast cells. $J$ Lasers Med Sci. 2017;8(suppl 1):S46-S50. doi: 10.15171/ jlms.2017.s9.

12. Kunimatsu R, Gunji H, Tsuka Y, Yoshimi Y, Awada T, Sumi $\mathrm{K}$, et al. Effects of high-frequency near-infrared diode laser irradiation on the proliferation and migration of mouse calvarial osteoblasts. Lasers Med Sci. 2018;33(5):959-966. doi: 10.1007/s10103-017-2426-0.

13. Doshi-Mehta G, Bhad-Patil WA. Efficacy of low-intensity laser therapy in reducing treatment time and orthodontic pain: a clinical investigation. Am J Orthod Dentofacial Orthop. 2012;141(3):289-297. doi: 10.1016/j.ajodo.2011.09.009.

14. Qamruddin I, Alam MK, Mahroof V, Fida M, Khamis MF, Husein A. Effects of low-level laser irradiation on the rate of orthodontic tooth movement and associated pain with self-ligating brackets. Am J Orthod Dentofacial Orthop. 2017;152(5):622-630. doi: 10.1016/j.ajodo.2017.03.023.

15. Kawasaki K, Shimizu N. Effects of low-energylaser irradiation on bone remodeling during experimental tooth movement in rats. Lasers Surg Med. 2000;26(3):282-91. doi: 10.1002/ (sici)1096-9101(2000)26:3<282::aid-lsm6>3.0.co;2-x.

16. Cruz DR, Kohara EK, Ribeiro MS, Wetter NU . Effects of low-intensity laser therapy on the orthodontic movement velocity of human teeth: a preliminary study. Lasers Surg Med. 2004;35(2):117-120. doi: 10.1002/lsm.20076.
17. Genc G, Kocadereli I, Tasar F, Kilinc K, El S, Sarkarati B. Effect of low-level laser therapy (LLLT) on orthodontic tooth movement. Lasers Med Sci. 2013;28(1):41-7. doi: 10.1007/ s10103-012-1059-6.

18. Tsuka Y, Fujita T, Shirakura M, Kunimatsu R, Su SC, Fujii E, et al. Effects of Neodymium-Doped Yttrium Aluminium Garnet (Nd:YAG) Laser Irradiation on Bone Metabolism During Tooth Movement. J Lasers Med Sci. 2016;7(1):40-4 doi: 10.15171/jlms.2016.09.

19. Redlich M, Asher Roos H, Reichenberg E, Zaks B, Mussig D, Baumert U, et al. Expression of tropoelastin in human periodontal ligament fibroblasts after simulation of orthodontic force. Arch Oral Biol. 2004;49(2):119-24. doi: 10.1016/j.archoralbio.2003.08.002.

20. Tunér J, Hode L. The New Laser Therapy Handbook: A guide for research scientists, doctors, dentists, veterinarians and other interested parties within the medical field. Grängesberg: Prima Books; 2010.

21. Hamblin MR, De Sousa M, Agrawal T, eds. Handbook of Low-Level Laser Therapy. Singapore: Pan Stanford Publishing Pte Ltd; 2017.

22. Tsuka Y, Kunimatsu R, Gunji H, Nakajima K, Kimura A, Hiraki T, et al. Effects of Nd:YAG low-level laser irradiation on cultured human osteoblasts migration and ATP production: in vitro study. Lasers Med Sci. 2019;34(1):55-60. doi: 10.1007/ s10103-018-2586-6.

23. de Melo Conti C, Suzuki H, Garcez AS, Suzuki SS . Effects of Photobiomodulation on Root Resorption Induced by Orthodontic Tooth Movement and RANKL/OPG Expression in Rats. Photochem Photobiol. 2019;95(5):1249-57. doi: 10.1111/php.13107.

24. Oliveira FA, Matos AA, Matsuda SS, Buzalaf MA, Bagnato VS, Machado MA, et al. Low level laser therapy modulates viability, alkaline phosphatase and matrix metalloproteinase-2 activities of osteoblasts. J Photochem Photobiol B. 2017;169:3540. doi: 10.1016/j.jphotobiol.2017.02.020.

25. Alazzawi MMJ, Husein A, Alam MK, Hassan R, Shaari R, Azlina A, et al. Effect of low level laser and low intensity pulsed ultrasound therapy on bone remodeling during orthodontic tooth movement in rats. Prog Orthod. 2018;19(1):10. doi: 10.1186/s40510-018-0208-2.

26. Tanaka H, Mine T, Ogasa H, Taguchi T, Liang CT. Expression of RANKL/OPG during bone remodeling in Vivo. Biochem Biophys Res Commun. 2011;411(4):690-4. doi: 10.1016/j. bbrc.2011.07.001.

27. Usumez A, Cengiz B, Oztuzcu S, Demir T, Aras MH, Gutknecht N. Effects of laser irradiation at different wavelengths $(660,810,980$, and $1,064 \mathrm{~nm})$ on mucositis in an animal model of wound healing. Lasers Med Sci. 2014;29(6):1807-13. doi: 10.1007/s10103-013-1336-z.

28. Naito K, Matsuzaka K, Ishigami K, Inoue T. Mechanical force promotes proliferation and early differentiation of bone marrow derived osteoblast-like cells in Vitro. Oral Med Pathol. 2009;13(4):143-9. doi: 10.3353/omp.13.143.

29. Okamoto A, Ohnishi T, Bandow K, Kakimoto K, Chiba N, Maeda A, et al. Reduction of orthodontic tooth movement by experimentally induced periodontal inflammation in mice. Eur J Oral Sci. 2009;117(3):238-47. doi: 10.1111/j.16000722.2009.00625.x.

30. Naruse S, Matsuzaka K, Kokubu E. Expressions of RANKL and OPG mRNA on Rat Periodontal Ligament Cells Following Heavy Mechnical Stress. Journal of Japan Association of Dental Traumatology. 2009;5(1):10-17. [Japanese]. 